\title{
Mengikat Karyawan Dengan Telecommuting (Studi Keterikatan Kerja Karyawan Telecommuting)
}

\section{EngagingEmployee Through Telecommuting (Study of Telecommuter Work Engagement)}

\author{
Nuri Sadida ${ }^{1} \&$ Zulfa Febriani ${ }^{2}$ \\ Fakultas Psikologi, Universitas YARSI, Jakarta, 10510, Indonesia \\ Email: nuri.sadida@yarsi.ac.id, zulfa.febriani@yarsi.ac.id
}

KATA KUNCI keterikatan kerja, telecommuting, telework, UWES engagement scale, jam kerja fleksibel, work-life balance

KEYWORDS work engagement, telecommuting, telework, UWES engagement scale, flexible work hours, work-life balance

ABSTRAK

ABSTRACT

Survei pada tahun 2012 menunjukkan bahwa hanya ada 1/3 karyawan yang memiliki keterikatan kerja dengan pekerjaannya di Indonesia. Salah satu sebab permasalahan yang dipersepsikan karyawan adalah kurangnya keseimbangan antara kehidupan kerja dan kehidupan pribadi. Hal ini terjadi karena belum banyak perusahaan yang menerapkan kebijakan jam kerja fleksibel. Akan tetapi, beberapa tahun belakangan beberapa perusahaan di Indonesia mulai menerapkan disain kerja telecommuting, sebuah disain kerja yang memungkinkan karyawan untuk tidak bekerja di kantor yang terpusat. Beberapa penelitian sebelumnya menyajikan beberapa keuntungan penerapan telecommuting, diantaranya meningkatnya produktivitas, kepuasan kerja, dan menurunnya stres kerja. Namun belum ada penelitian yang meneliti perbedaan tingkat keterikatan kerja pada karyawan yang bekerja di kantor tersentralisasi dengan karyawan telecommuting. Oleh karena itu, penelitian ini bertujuan untuk mengetahui perbedaan tersebut. Sejumlah 53 karyawan berpartisipasi dalam penelitian ini, dimana jumlah karyawan telecommuting adalah 21 karyawan dan karyawan yang bekerja tersentralisasi sejumlah 32 orang. Dimensi keterikatan kerja yang diukur adalah absorpsi, dedikasi, dan semangat. Pengambilan data menggunakan kuesioner Utrecht Work Engagement Scale (UWES) dengan 17 aitem yang diadaptasikan. Data dianalisis menggunakan teknik statistik non parametrik. Hasilnya dapat disimpulkan bahwa kelompok karyawan telecommuting menunjukkan rata-rata tingkat keterikatan kerja yang lebih tinggi secara signifikan dibandingkan kelompok karyawan yang bekerja tersentralisasi ( $U=$ 180,5 , $p=.005$ ). Hasil dari penelitian ini diharapkan dapat menjadi masukan bagi perusahan di Indonesia untuk mempertimbangkan penerapan telecommuting.

Survey about employee engagement held in 2012 showed that only a third of employees have high level of employee engagement in Indonesia. According to survey, employees feel low level of engagament to their work is because they experienced the lack of balance between work life and personal life. There are only a few companies in Indonesia 
implementing flexible working hours policy. However, in recent years several companies in Indonesia started implementing telecommuting as a new job design. This design allows employees work outside centralized office. Several previous studies presents a lot of advantages of telecommuting, namely increased productivity, job satisfaction, and decreased job stress. However, there is a little study has examined the difference levels of work engagement between employees who work in a centralized office compare to those who work remotely as telecommuters. Therefore, this study aims to determine the employee engagement differences between those two groups of employee. There are 53 subjects participated in this study, 21 subject work as telecommuter, and 32 subject working in centralized office. Employee engagement measurement using Utrecht Work Engagement Scale (Uwes) which adapted to Indonesian language. This scale consists of 17 items measuring dimensions of the working attachment namely absorption, dedication, and passion. Data were analyzed using non-parametric statistical techniques. It can be concluded that employee engagement level in telecommuting group was statistically significantly higher than the sentralized worker group $(U=180,5, p=.005)$. The results of this study are expected to be considered for adopting telecommuting.

\section{PENDAHULUAN}

Kualitas kepuasan kerja karyawan Indonesia saat ini menunjukkan gejala yang cukup memprihatinkan. Dalam sebuah survei yang dilaporkan oleh Accenture, tercatat bahwa hanya ada $18 \%$ pekerja di Indonesia yang puas dan bahagia dalam pekerjaannya (BusinessInsider.com, 2012). Isu kebahagiaan kerja karyawan memang sering muncul menjadi isu dalam banyak survei karyawan selama beberapa tahun terakhir seiring dengan perkembangan ekonomi global yang tidak begitu baik. Termasuk dalam survei yang dilakukan oleh Nielsen Indonesia pada tahun 2012, disebutkan bahwa perhatian utama karyawan saat ini adalah pada keseimbangan hidup kerja dan keluarga, setelah stabilitas ekonomi. Disebutkan juga dari hasil wawancara responden penelitian yang sama, bahwa beban pekerjaan semakin meningkat dan imbasnya stres juga semakin meningkat beberapa tahun terakhir (JakartaPost, 2012). Peningkatan stres karyawan tentu dapat berimbas negatif, tidak hanya pada produktivitas individu, namun juga organisasi atau perusahaan. Efek negatif pada perusahaan di antaranya meningkatnya beban kompensasi kesehatan karena kesehatan karyawan terganggu, biaya operasional seperti pengeluaran biaya gaji tetap, dan terganggunya produktivitas perusahaan secara keseluruhan.

Baik perusahaan maupun karyawan memiliki peran dalam manajemen stres di tempat kerja. Salah satu metode yang dapat dipertimbangkan perusahaan mengelola stres karyawan adalah dengan menyeleksi dan meningkatkan keterikatan karyawan. Karakteristik karyawan dengan keterikatan tinggi di antaranya merasa terlibat, puas, antusias dengan pekerjaan yang mereka lakukan. Dalam studi yang dilakukan oleh Global Workforce Study (GWS) pada tahun 2012 untuk meneliti tingkat keterikatan karyawan di Indonesia disebutkan bahwa karyawan dengan tingkat keterikatan yang tinggi umumnya mampu mengelola tingkat stres kerja yang dihadapinya (Towers Watson, 2012).Pada penelitian lain ditemukan bahwa unit bisnis dengan tingkat keterikatankerja karyawan yang tinggi mempunyai tingkat kepuasan pelanggan yang lebih tinggi, lebih produktif, memiliki keuntungan yang lebih tinggi, serta tingkat perputaran karyawan (turn over) dan kecelakaan lebih rendah. (Harter, Schmidt, \& Hayes, 2002 dalam Robbins, 2007). 
Namun meningkatkan keterikatan karyawan bukan perkara mudah. Survei menyatakan bahwa hanya 1/3 karyawan di Indonesia memiliki keterikatan yang tinggi (Towers Watson, 2012). Dari angka tersebut, $27 \%$ karyawan Indonesia mengatakan kemungkinan dalam dua tahun yang akan datang akan meninggalkan pekerjaan saat ini, sementara $42 \%$ karyawan yakin bahwa mereka harus meninggalkan perusahaan saat ini.

Usaha meningkatkan keterikatan karyawan membutuhkan komitmen yang serius dari manajemen perusahaan, dikarenakan akar dari tingkat keterikatan yang rendah adalah tata kelola manajemen yang buruk (Kular dkk, 2008). Organisasi yang tidak mampu mengondisikan peningkatan keterikatan karyawan menghadapi resiko tinggi kehilangan anggotanya.Oleh karena itu, manajemen perlu memperhatikan faktor apa saja yang menjadi perhatian utama karyawan untuk terlibat dalam pekerjaannya. Menurut karyawan, fleksibilitas yang disediakan manajemen perusahaan merupakan salah satu faktor terpenting yang dapat meningkatkan kebahagiaan dan keterikatan karyawan. Fasilitas berupa jam kerja, lokasi kerja, dan kebijakan yang fleksibel dianggap dapat membantu menurunkan stres kerja, mendukung keseimbangan kualitas hidup, meningkatkan kebahagiaan dan keterikatan karyawan.

Salah satu program disain kerja yang semakin populer di berbagai Negara yang memberikan unsur fleksibilitas tersebut adalah telecommuting. Program telecommutingadalah perjanjian antara karyawan dan pemberi kerja dimana karyawan dapat bekerja paruh atau penuh waktu dari lokasi alternatif selain kantor yang tersentralisasi, seperti misalnya di rumah atau tempat kerja lain, menggunakan media elektronik untuk berinteraksi dengan karyawan lain di dalam dan di luar organisasi (Bailey \& Kurland, 2002)

Keuntungan dari penerapan telecommuting ini dapat dirasakan baik oleh karyawan maupun organisasi atau perusahaan. Dari sisi karyawan, keuntungan telecommuting di antaranya dapat meningkatkan kepuasan kerja, menurunkan stres kerja, mengurangi ongkos dan biaya pribadi. Dari sisi perusahaan, telecommuting dapat menurunkan beban biaya akomodasi perusahaan seperti beban penyediaan ruang kerja, parkir, serta juga menurunkan biaya pengobatan karyawan(Meadows, 2007). Hal positif ini juga dirasakan oleh PT. Microsoft Indonesia yang telah menerapkan pola telecommuting. Menurut HR Director Microsoft Indonesia, saat Jakarta terkena banjir besar pada tahun 2013, kegiatan operasional PT. Microsoft Indonesia masih tetap dapat berjalan karena karyawan mereka dapat bekerja di mana saja (http://www.portalhr.com/berita/jakartabanjir-karyawan-microsoft-indonesiaterbantu-sistem-telecommuting/)

Namun penerapan Telecommuting tidak selalu membawa dampak positif. Seperti yang diungkapkan oleh Brueggeman dalam Sukoco (2007), kerugian telecommuting yang dirasakan oleh karyawan di antaranya karyawan merasa terkucil dari rekan kerjanya, merasa kehilangan interaksi sosial, menambah tingkat stres pada rumah tangga, serta kurang menguntungkan bagi karir di masa yang akan datang.

Oleh karena itu dalam penelitian ini akan digali lebih lanjut apakah penerapan program telecommuting berperan dalam mempengaruhi tingkat keterikatan karyawan di Jakarta. Hasil dari penelitian ini diharapkan dapat memberikan masukan kepada manajemen perusahaan tentang hubungan program telecommuting dengan peningkatan keterikatan karyawan.

\section{Keterikatan Kerja Karyawan}

Konsep keterikatan kerja karyawan bermula dari konsep keterikatan personal (personal engagement)di tempat kerja yang dicetuskan oleh Kahn pada tahun 1990. Kahn mengumpulkan data dari konselor kamp dan menemukan bahwa para konselor kamp ini mengalami keterikatan secara 
emosional, kognitif, dan fisik dengan pekerjaan mereka. Kahn (1990) dalam Kullar, dkk (2008) mendefinisikan keterikatan kerja karyawan sebagai "perasaan terikat anggota organisasi dengan peran mereka dalam pekerjaan; dalam proses pembentukan keterikatan kerja, anggota organisasi bekerja dan mengekspresikan diri mereka secara fisik, kognitif, dan emosional selama menjalankan peran kerja.

Keterikatan kognitif tergambar dalam kepercayaan karyawan terhadap organisasi, pemimpin organisasi, dan kondisi pekerjaan. De Lacy (2009) menjabarkan keterikatan kerja kognitif adalah pemahaman karyawan akan peran mereka dalam konteks mencapai tujuan dan sasaran organisasi. Sementara aspek fisik dariketerikatan kerja karyawan adalah besarnya energi fisik yang dikeluarkan oleh karyawan dalam pekerjaan untuk menyelesaikan tugasnya. Pada aspek ini, Kahn menjelaskan lebih lanjut bahwa aspek fisik dalam keterikatan kerjabukan berarti mengerahkan usaha fisik yang besar dalam bekerja, melainkan lebih ke seberapa waspada dan kompeten karyawan menjalankan peran kerja mereka, atau 'menghadirkan jiwa' ketika bekerja. Macey dan Schneider (2008) mendefinisikan aspek ini sebagai keterikatan kerjadalam bentukperilaku, yang dijelaskan sebagai perilaku adaptif yang bertujuan untuk mencapai tujuan organisasi.

Aspek emosional menggambarkan apa yang dirasakan karyawan tentang organisasi, pimpinan organisasi, dan lingkungan pekerjaan, termasuk sikap positif dan negatif karyawan terhadap organisasi dan pimpinannya. Ada perasaan terhubung secara emosi dengan organisasi, atau dengan sesuatu atau seseorang di dalam organisasi (Kahn dalam De Lacy, 2009). Menurut Kahn, keterikatan kerjaseseorang terbentuk apabila kondisi psikologis dan fisik tersebut muncul dalam diri karyawan ketika bekerja dan berusaha menunjukkan kinerja dalam sebuah organisasi.
Kahn melihat bahwa keterikatan tersebut berbeda dengan motivasi, kepuasan kerja, atau keterlibatan kerja. Dari pengalaman tersebut, lalu Kahn mencetuskan keterikatan kerjakaryawan (employee engagement) sebagai konstruk psikologis. Di kemudian hari, konstruk employee lebih populer karena dipublikasikan oleh organisasi Gallup

Karyawan

yang terikat(engaged)memiliki semangat dan perasaan terhubung yang dalam dengan pekerjaannya, sebaliknya karyawan yang tidak terikat (disengaged) memiliki sedikit antusiasme dan energi dalam bekerja. Karyawan yang aktif disengaged secara umum tidak bahagia dan tidak tertarik dengan pekerjaannya, dan bahkan menularkan perasaan tidak bahagianya sehingga merusak karyawan lain yang terikat.

Beberapa pandangan memiliki perbedaan pendapat tentang munculnya keterikatan kerjapada seseorang. Sebagian peneliti berpendapat bahwa keterikatan kerja timbul akibat dari aspek yang ada di tempat kerja (Harter dalam Kular dkk, 2008). Sementara penelitian lain menyebutkan bahwa keterikatan kerja adalah karakteristik yang sudah ada dalam individu, yang diterapkan dalam tempat kerja (Harter dkk 2002 dan Goddard 1999). Menurut Robbinson (2006) keterikatan kerja karyawan dapat dibangun melalui pengkondisian lingkungan organisasi dimana emosi-emosi positif seperti keterlibatan dan kebanggaan harus dibangun.

Jika dikembalikan kepada dimensi dari keterikatan kerjakaryawan yang terdiri dari dimensi kognitif, afektif, dan perilaku. Maka dapat disimpulkan bahwa keterikatan kerjadapat dipengaruhi dan dibentuk oleh faktor lingkungan.

\section{Dimensi dan Pengukuran Keterikatan Kerja Karyawan}

Terdapat beberapa pengukuran yang sudah pernah dibuat dalam pengukuran dimensi keterikatan kerja. Salah satu yang 
cukup sering digunakan adalah Utrecht Work Engagement Scale (UWES). Alat ukur ini pertama kali dibuat dan divalidasi oleh Schaufeli, Salanova, Gonzales, dan Bakker pada tahun 2002. Alat ukur ini terdiri dari 3 sub skala :

1. Semangat (Vigor), terdiri dari 5 aitem, untuk mengukur tingkat energi, resiliensi, dan ketangguhan. Contoh aitemnya "Saya dapat bekerja terus menerus dalam waktu yang lama".

2. Dedikasi (Dedication), terdiri dari 6 aitem, untuk mengukur antusiasme, kebanggaan, tantangan dalam pekerjaan, memiliki tujuan, dan merasa terinspirasi. Contoh aitemnya "Pekerjaan saya menginspirasi saya"

3. Penyerapan (Absorption), mengukur sejauh apa seseorang merasa terserap dalam pekerjaannya.

Setelah versi awal ini, di kemudian hari muncul versi alat ukur yang mengukur 3 subskala yang sama dengan aitem yang lebih sedikit (9 aitem) yang dikembangkan oleh Schaufeli, Bakker, dan Salanov pada tahun 2006. Pada tahun 2010, Rich, Lepine, dan Craword mengembangkan Job Engagement Scale (JES) untuk mengukur 3 dimensi keterikatan kerja yang pertama kali dicetuskan oleh Kahn $(1990,1992)$, yaitu investasi energi fisik, emosional, dan kognitif dalam tugas pekerjaan. Alat ukur ini terdiri dari 18 aitem, dengan masingmasing 6 aitem pada setiap dimensi.

\section{Telecommuting}

Telecommuting pertama kali dicetuskan oleh Jack Niles pada tahun 1973, yaitu jenis pekerjaan yang dapat dilakukan di lokasi yang tidak membutuhkan banyak waktu untuk pergi dan pulang ke tempat kerja, pekerjaan yang dapat dilakukan di dalam rumah atau di lokasi kerja yang lain, dan difasilitasi oleh jaringan internet/ komputer/ telepon, termasuk peralatan kerja lain seperti alat tulis kantor (ATK). Pemerintah Amerika Serikat mendefinisikan telecommuting sebagai kemampuan untuk melakukan pekerjaan di lokasi selain dari kantor resmi, yang dilakukan secara rutin, teratur, dan dilakukan lebih dari satu hari dalam sepekan (Woog dalam Olorunfemi , 2013).

Jam kerja karyawan telecommute bervariasi, mulai dari hanya beberapa jam di luar kantor dalam sepekan, hingga sepenuhnya berada di luar kantor (Crandall \& Grao, 2005). Menurut Robbins (2007), ada tiga kategori pekerjaan yang dapat dikerjakan dengan telecommuting, yaitu pekerjaan yang mengelola informasi secara rutin, pekerjaan yang membutuhkan aktivitas banyak berpindah tempat, serta tugas-tugas professional atau pekerjaan yang membutuhkan pengetahuan spesifik untuk mengerjakannya. Profesi seperti penulis, pengacara, analis, dan karyawan yang perlu sering mengakses komputer atau menggunakan telepon sesuai bekerja dengan metode telecommuting.

Umumnya pengaturan pekerjaan telecommuting secara teknis diatur dalam perjanjian kerja formal antara perusahaan dengan karyawan pelaku telecommuting. Dalam perjanjian formal, diatur keterangan pada hari apa saja karyawan akan bekerja di luar kantor pusat, jumlah jam yang akan diluangkan oleh karyawan untuk menangani klien/ pelanggan, jumlah pesan yang akan dibalas, dan tujuan atau tenggat waktu yang diperlukan untuk karyawan menyelesaikan sejumlah tugas. Namun tidak semua pekerjaan telecommuting diatur dalam perjanjian kerja resmi, pekerjaan telecommuting yang tidak didukung oleh surat/ kontrak kerja formal umumnya lebih fleksibel dalam pengaturan pelaksanaan telecommuting di tataran teknis. Telecommuting informal umumnya hanya menyediakan sedikit atau bahkan satu pekerjaan untuk diselesaikan dalam kurun waktu tertentu. (CWF, 2002)

\section{Dampak telecommuting terhadap organisasi dan individu}

Dari sisi perusahaan, menerapkan telecommuting dapat mengurangi biaya yang terkait dengan akomodasi fisik karyawan, seperti biaya properti dan 
pemeliharaaan properti, serta biaya fasilitas kesehatan karena turunnya jumlah karyawan yang sakit (Meadows, 2007). Penelitian dari Heneman dan Greenberger (2002), dan Johnson (2004) membuktikan bahwa karyawan dalam organisasi virtual bertahan kerja dalam periode yang lama, sehingga mengurangi biaya rekrutmen karyawan baru.

Sementara dari sudut pandang karyawan, telecommuting dianggap sebagai sebuah hak istimewa dimana mereka memiliki kesempatan untuk bekerja sekaligus mengatur pekerjaan rumah tangga, mengurus anak dalam keadaan darurat, dan sebagainya. Hal ini menimbulkan perasaan "berhutang" dalam diri karyawan, yang menyebabkan karyawan sering merasa bersalah jika mengambil waktu istirahat. Dampak lain dari perasaan berhutang itu adalah karyawan bekerja lebih lama daripada karyawan lain yang bekerja di kantor pusat, supaya tetap mendapatkan hak istimewa bekerja secara telecommute.

Dampak sosial dan psikologis yang mungkin muncul dalam penerapan telecommuting di antaranya :

1. Timbul perasaan iri dari karyawan yang tidak mendapatkan kesempatan telecommuting kepada karyawan telecommuting.

Perasaan iri ini dapat terjadi karena mereka tidak mendapatkan kesempatan untuk telecommuting, atau terjadi karena karyawan yang tidak telecommuting mendapatkan tumpukan/ limpahan pekerjaan yang lebih banyak dari karyawan telecommuting

2. Mengembangkan budaya kerja yang penuh kepercayaan.

Menerapkan telecommuting membutuhkan tingkat kepercayaan yang tinggi antar karyawan dan antar karyawan dengan atasan. Atasan yang belum mampu atau sulit untuk mengontrol pekerjaan bawahan yang tidak di tempat akan sulit untuk memiliki karyawan telecommuting. Untuk mengatasi hal ini, penting agar mekanisme kontrol dan pekerjaan telecommuting diatur dengan baik dalam sebuah perjanjian kerja formal.

3. Perubahan komitmen organisasi dan loyalitas karyawan

Beberapa penelitiberpendapat bahwa telecommuting akan menurunkan tingkat komitmen organisasi dan loyalitas karyawan dikarenakan karyawan tidak berada di kantor pusat dan bekerja bersama karyawan lain. Telecommuting juga meningkatkan perasaan kemandirian pada karyawan, dan frekuensi berada di rumah menyebabkan masalah yang terjadi di rumah dianggap lebih penting oleh karyawan dibanding masalah pekerjaan. Akan tetapi penelitian saat ini menunjukkan bahwa hampir $80 \%$ dari pelaku telecommuting merasakan komitmen yang lebih besar dan kebanyakan berencana untuk tetap bekerja di perusahaan saat ini (CWF dalam Telecommute Connecticut, 2002). Salah satu utuk mempertahankan komitmen karyawan telecommuting adalah dengan meminta mereka tetap mengunjungi kantor pusat secara teratur dan tetap terlibat dengan isu-isu kantor. (CWF dalam Chapman, Sheeney, Heywood, Dooley, \&Collins, 1995).

\section{Penelitian tentang Keterikatankerja Karyawan dan Telecommuting}

Beberapa penelitian tentang keterikatan kerja karyawan di Indonesia melihat hubungan antara keterikatan kerja karyawan dengan budaya organisasi (Nirmala, 2010, Ayu dkk, 2013), yang menyebutkan bahwa budaya organisasi mempengaruhi keterikatan kerja karyawan. Penelitian lainnya yang dilakukan oleh Megani (2012) menghasilkan bahwa karyawan yang memiliki keterikatan kerja tinggi lebih siap untuk berubah 
dibandingkan dengan karyawan yang tidak merasakan keterikatan kerja.

Tidak banyak penelitian yang sudah membahas hubungan antara telecommuting dengan keterikatan kerja karyawan, khususnya di Indonesia. Menurut penelusuran peneliti, terdapat dua penelitian yang sudah dilakukan yang membahas hubungan antara telecommuting dengan keterikatan kerja karyawan. Penelitian yang pertama yang dilakukan oleh Boeh di Angkatan Udara Wright Patterson pada tahun 2003, dimana penelitian tersebut meneliti perbedaan keterikatan kerja antara karyawan yang diberi kesempatan untuk telecommuting dan yang tidak. Hasil dari penelitian tersebut menunjukkan bahwa tidak ada perbedaan keterikatan kerja karyawan yang signifikan antara kelompok karyawan yang melakukan telecommuting dan yang tidak.

Penelitian selanjutnya dilakukan oleh Gallup pada tahun 2013 dan dilaporkan pada State of the American Workplace: Employee Engagement Insights for U.S. Business Leaders, dan hasilnya adalah karyawan yang diberi kesempatan mengerjakan 20 persen pekerjaannya secara telecommuting adalah karyawan yang menunjukkan level keterikatan kerjayang paling tinggi. Sementara tingkat keterikatan kerja karyawan semakin menurun apabila mereka diberikan kesempatan lebih sering untuk telecommuting. Namun penurunan keterikatan kerja tersebut tidak lebih rendah daripada karyawan yang tidak diberikan kesempatan untuk telecommuting sama sekali.

Berdasarkan paparan di atas, maka tujuan dari penelitian ini adalah untuk mengetahui perbedaan tingkat keterikatan kerja karyawan antara karyawan yang bekerja di kantor tersentralisasi dengan karyawan yang bekerja secara telecommuting.

Diharapkan hasil dari penelitian ini dapat menambah literatur tentang keterikatan kerja karyawan dan telecommuting, serta bermanfaat bagi organisasi atau perusahaan yang bermaksud menerapkan telecommuting dengan mengetahui dampak dari telecommuting terhadap keterikatan kerja karyawan

\section{METODE PENELITIAN}

Penelitian ini merupakan penelitan ex post facto, dimana peneliti tidak memberikan intervensi kepada subjek, jenis komparatif dimana peneliti bermaksud menyelidiki perbedaan tingkat keterikatan kerja karyawan pada dua kelompok independen sebagai akibat dari penerapan telecommuting.

Pada penelitian ini pemilihan dan pengambilan sampel dilakukan dengan metode Accidental Sampling, dengan kriteria subjek :
a. Karyawan yang bekerja secara telecommuting

b. Karyawan yang bekerja di kantor tersentralisasi

Jumlah subjek yang berpartisipasi pada penelitian ini sejumlah 73 karyawan, namun hanya 53 kuesioner yang dapat diolah sebagai data penelitian. Terdiri dari 32 karyawan yang bekerja secara tersentralisasi, dan 21 karyawan yang bekerja secara telecommuting.

Untuk mengukur keterikatan kerja dalam penelitian ini, peneliti mengadaptasi Utrecht Work Engagement Scale (UWES), yang divalidasi oleh Schaufeli, Salanova, Gonzales, dan Bakker pada tahun 2002. Alat ukur ini terdiri dari 3 sub skala :

1. Semangat (Vigor), terdiri dari 5 aitem, mengukur tingkat energy, resiliensi, dan ketangguhan. Contoh "Saya dapat bekerja terus menerus dalam waktu yang lama".

2. Dedikasi (Dedication), terdiri dari 6 aitem, untuk mengukur antusiasme, kebanggaan, tantangan dalam pekerjaan, memiliki tujuan, dan merasa terinspirasi. Contoh aitemnya "Pekerjaan saya menginspirasi saya"

3. Penyerapan (Absorption), terdiri dari 6 aitem mengukur sejauh apa seseorang merasa terserap dalam pekerjaannya. Contoh aitem ini misalnya "Ketika saya bekerja, saya lupa segala sesuatu di 
sekitar sayaPada penelitian ini, uji realibilitas menggunakan internal consistency dengan teknik analisis Alpha Croncbach. Berdasarkan uji psikometri alat ukur, didapatkan hasil reliabilitas pada skala keterikatan kerjakaryawan sebesar 0,907. Hasil tersebut menjelaskan bahwa skala dapat diandalkan atau reliabel. Sementara pada hasil uji validitas aitem, didapatkan hasil bahwa setiap aitem memiliki nilai validitas di atas 0,2 , sehingga dapat disimpulkan bahwa setiap aitem dalam kuesioner ini valid atau dapat mengukur apa yang ingin diukur

\section{ANALISIS DAN HASIL}

\section{Deskripsi Data}

Berdasarkan perhitungan data deskripsi, didapatkan skor rata-rata empirik adalah sebesar 50,15, dan nilai standar deviasi sebesar 6,631. Jumlah responden yang berpartisipasi adalah sebesar 53 orang, dengan jumlah karyawan telecommuting sebesar 39,6\% dan karyawan sentralisasi sebesar $60,4 \%$. Jenis kelamin responden perempuan sebesar 22 orang $(41,5 \%)$, dan laki-laki sebesar 31 orang (31\%).

\section{Hasil Uji normalitas}

Uji normalitas sebaran data dilakukan dengan menggunakan uji komolgorov-smirnov. Dari hasil uji sebaran data, diperoleh nilai Asymp. Sig (2-tailed) adalah sebesar 0,0004, dimana nilai tersebut berada di bawah kriteria signifikansi $\alpha$ $(0,005)$. Dengan demikian, sebaran data pada penelitian terdistribusi tidak normal. Selanjutnya, pengolahan data selanjutnya akan menggunakan uji perbedaan independent sample test dengan statistik non parametrik menggunakan rumus Man Whitney.

\section{Hasil Uji Hipotesis Penelitian}

Dari hasil uji perbedaan antar kelompok independen dengan menggunakan rumus Man Whittney, didapatkan nilai keterikatan kerja pada kelompok karyawan telecommuting menunjukkan nilai yang lebih tinggi secara signifikan dibandingkan kelompok karyawan yang bekerja tersentralisasi $(U=$ $180,5, p=.005)$. Angka ini berada di bawah nilai $\alpha(0,05)$, yang artinya terdapat perbedaan nilai keterikatan kerja yang signifikan antara kedua kelompok karyawan. Dimana rata-rata kelompok karyawan yang bekerja secara telecommuting memiliki nilai yang lebih tinggi, yaitu 53,52. Sementara kelompok karyawan yang bekerja secara tersentralisasi memiliki nilai rata-rata yang lebih rendah yaitu 47,94.

\section{Kategori tingkat keterikatan kerja karyawan}

Untuk mengetahui sebaran kategorisasi nilai keterikatan kerja karyawan, peneliti membagi keterikatan kerja karyawan menjadi 3 kategori, yaitu : tinggi, rata-rata, dan rendah yang dapat dilihat pada tabel berikut:

Tabel 3. Kategorisasi Tingkat Keterikatan Kerja Pada Karyawan Telecommuting dan Sentralisasi

\begin{tabular}{lcccc}
\hline \multirow{2}{*}{ Skor } & & \multicolumn{2}{c}{ Jumlah } & Total \\
\cline { 3 - 4 } & Kategori & Sentralisasi & Telecommuting & \\
& & & 8 & 11 \\
$\mathrm{X}>56,781$ & Tinggi & 3 & 12 & 36 \\
$43,519<\mathrm{X}<56,781$ & Sedang & 24 & 1 & 6 \\
$\mathrm{X}<43,519$ & Rendah & 5 & \\
\hline
\end{tabular}

\section{DISKUSI}

Hasil utama yang didapat pada penelitian ini menyatakan bahwa terdapat perbedaan keterikatan kerja karyawan yang signifikan antara karyawan yang bekerja secara 
telecommuting dengan karyawan yang bekerja secara tersentralisasi, dengan tingkat keterikatan kerja karyawan telecommuting yang lebih tinggi dibandingkan dengan karyawan yang bekerja secara tersentralisasi. Pada umumnya perusahaan yang menerapkan disain kerja telecommuting adalah perusahaan yang bergerak di bidang media, konsultasi, atau telekomunikasi. Budaya perusahaan-perusahaan tersebut umumnya dinamis, dimana kinerja karyawan lebih dinilai dari hasil kerja yang dihasilkan daripada proses kerjanya. Manajemen yang menerapkan telecommuting dalam perusahaannya menunjukkan bahwa manajemen memiliki pendekatan inovatif. Apabila dikaitkan dengan penelitian Ayu, Yusuf, dan Priyatama (2013), yang mengatakan bahwa terdapat hubungan antara keterikatan kerja karyawan dengan budaya kerja, dapat diduga adanya skor keterikatan kerja yang lebih tinggi pada karyawan yang bekerja secara telecommuting dikarenakan pengaruh budaya organisasi yang dinamis dan berorientasi pada hasil.Namun pada penelitian ini, hal tersebut tidak diteliti lebih lanjut.

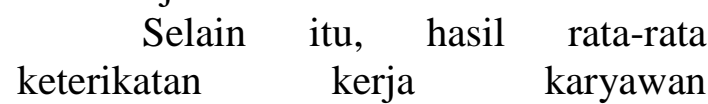
telecommuting yang lebih tinggi dapat diduga karena menurut penelitian The Center of Work and Family (2002), karyawan telecommuting menganggap telecommuting adalah sebuah keuntungan, sehingga karyawan telecommuting cenderung bekerja lebih lama daripada karyawan yang bekerja di kantor pusat agar mereka tetap memperoleh hak istimewa sebagai karyawan telecommuting.

Walaupun hasil yang didapat dari penelitian ini menunjukkan terdapat perbedaan yang signifikan, namun hasil ini belum dapat digeneralisir untuk kelompok atau populasi yang lebih luas, dikarenakan responden penelitian ini hanya sejumlah 53 responden. Untuk mendapatkan gambaran yang lebih mendalam, peneliti menyarankan agar penelitian selanjutnya dapat menambah lebih banyak responden. Selain itu, sebaran data yang tidak normal diduga disebabkan karena alternatif jawaban pada kuesioner hanya menggunakan 4 alternatif jawaban. Sebaiknya untuk penelitian selanjutnya dapat menggunakan kuesioner dengan lebih banyak alternatif jawaban, dan dilengkapi dengan metode pengambilan data yang lain seperti wawancara.

Hasil dari pembahasan ini menambahkan daftar positif keuntungan penerapan telecommuting. Telecommuting juga memiliki pengaruh yang signifikan terhadap konstruk psikologis lain, di antaranya mempengaruhi kebahagiaan dan stres kerja karyawan. Menurut Fonner \& Rollof (2010), karyawan telecommuting lebih bahagia dan merasakan lebih sedikit stres kerja dibandingkan dengan karyawan yang bekerja secara tersentralisasi dikarenakan karyawan telecommuting tidak banyak berinteraksi dengan rekan kerja dan karenanya terhindar dari gangguan rekan kerja dan politik kantor. Selain itu karyawan telecommuting juga mempersepsikan konflik antara pekerjaan dan keluarga yang lebih sedikit. Menurut Fonner lagi, keberadaan rekan kerja memang dibutuhkan untuk kebutuhan bersosialisasi, namun menimbulkan distraksi saat bekerja.

Akan tetapi hasil dari penelitian ini memiliki perbedaan dengan penelitian yang dilakukan oleh Boeh (2003) yang meneliti apakah penerapan program telecommuting pada pegawai Angkatan Udara di Amerika Serikat dapat meningkatkan keterikatan kerja karyawan. Hasil dari penelitian Boeh menyatakan bahwa tidak terdapat 
perbedaan keterikatan kerja pada karyawan telecommuting dan yang bekerja di kantor secara tersentralisasi. Perbedaan hasil antara penelitian ini dan penelitian Boeh bisa jadi disebabkan karena alat ukur untuk mengukur keterikatan kerja karyawan pada penelitian Boeh berbeda dengan alat ukur penelitian ini, dimana Boeh menggunakan alat ukur Q12 dari Gallup, dan penelitian ini mengadaptasi kuesioner UWES. Selain itu juga terdapat perbedaan karakteristik subjek antara penelitian Boeh dan penelitian ini.

\section{SIMPULAN}

Dari hasil dan pembahasan yang sudah dipaparkan pada bab sebelumnya, dapat disimpulkan bahwa hasil dari penelitian ini adalah :

1. Karyawan telecommuter memiliki perbedaan tingkat keterikatan kerja kerja secara signifikan dibandingkan dengan karyawan yang bekerja secara tersentralisasi

2. Karyawan telecommuter memiliki tingkat keterikatan kerja yang lebih tinggi dibandingkan dengan karyawan yang bekerja secara tersentralisasi.

3. Terdapat 11 orang karyawan dengan tingkat keterikatan kerja yang tinggi, 36 orang dengan tingkat keterikatan kerja sedang, dan 6 orang dengan tingkat keterikatan kerja yang rendah.

\section{SARAN}

Beberapa catatan evaluasi dalam pelaksanaan penelitian beserta saran perbaikan untuk penelitian lanjutan diantaranya adalah :

1. Jumlah responden yang sedikit, yaitu sejumlah 53 responden. Untuk melakukan penelitian lanjutan yang menargetkan responden telecommuter dapat menargetkan beberapa perusahaan yang memiliki banyak karyawan telecommuter, seperti perusahaan IT dan perusahaan media.
2. Data yang diperoleh melalui kuesioner UWES yang hanya memiliki 17 aitem dikhawatirkan kurang menggambarkan kondisi keterikatan kerja karyawan, walaupun kuesioner adaptasi UWES dalam penelitian ini memiliki tingkat reliabilitas internal dan validitas yang baik. Penelitian selanjutnya dapat menggunakan pengambilan data sekunder berupa wawancara untuk memperoleh kedalaman data.

3. Sebaran data yang tidak normal diduga karena alternatif jawaban dalam kuesioner hanya ada empat alternatif. Berbeda dengan kuesioner UWES versi original yang menggunakan 6 alternatif jawaban.

4. Sebagai tambahan analisa data, penelitian selanjutnya dapat menganalisa berdasarkan industri/ core business perusahaan. Analisa berdasarkan kekhasan industri perusahaan tidak memungkinkan untuk dilakukan pada penelitian ini karena jumlah responden yang kurang, serta subjek yang berpartisipasi dalam penelitian ini sebagai besar berasal dari industri teknologi informasi.

5. Kendala yang ditemui selama penelitian adalah kesulitan untuk mendapatkan subjek telecommuter. Beberapa perusahaan dan organisasi yang peneliti ketahui menerapkan telecommuting tidak bersedia untuk dijadikan tempat penelitian atau sulit dihubungi untuk mendapatkan izin. Sehingga peneliti menggunakan pendekatan secara personal kepada karyawan telecommuter melalui media sosial.

6. Kategori keterikatan kerja karyawan berdasarkan teori Drake (2012) dikategorikan menjadi lima, yaitu sangat tinggi, tinggi, rata-rata, rendah, dan sangat rendah. Hasil penelitian ini tidak memungkinkan untuk dibagi 
menjadi lima kategori dikarenakan hasil data penelitian ini berasal dari kuesioner adaptasi yang memiliki alternatif jawaban yang berbeda dengan kuesioner UWES asli.

\section{DAFTAR PUSTAKA}

Ayu, L, M. Yusuf, dan A. N. Priyatama. 2013. Hubungan antara Employee Satisfaction dan Budaya Organisasi dengan Employee Engagement pada Karyawan Tetap PT. BPD Jawa Tengah Cabang Utama Semarang. Jurnal Ilmiah Psikologi Candrajiwa 2 (2). Universitas Nasional Sebelas Maret.

Bailey, D. E., dan N. B. Kurland. 2002. A review of telework research: Findings, new directions and lessons for the study of modern work. Journal of Organizational Behavior 23: 383-400.

Boeh, D. J. 2003. An Analysis of Engagement of Those Who Telecommute vs Those Who Do Not. Thesis. Department of the Air Force Air University

BusinessInsider. 2012. Indonesian Employees Are The Most Unhappy With Their Jobs. http://www.businessinsider.com/si ngapore-employees-are-amongthe-most-dissatisfied-with-theirjobs-2012-3

De Lacy, J. C. 2009. Employee Engagement: The Development of a Three Dimensional Model of Engagement; and an Exploration of Its Relationship with Affective Leader Behaviours. Tesis. Faculty of Management. Queensland University of Technology. Brisbane

Drake, T. J. 2012. Assessing Employee Engagement : a Comparison of the Job Engagement Scale and the Utrecht Work Engagement Scale.
Tesis. Department of Psychology. Colorado State University. Colorado.

Fonner, K.F \& Rollof, M (2010). Why Teleworkers are More Satisfied with Their Jobs than are OfficeBased Workers: When Less Contact is Beneficial. Journal of Applied Communication Research. Vol. 38 issue 4.

Gallup. 2013. State of the American Workplace: Employee Engagement Insights for U.S. Business Leaders. Gallup. USA

Gay, L. R., P. L. Diehl P. L.1992. Research methods for business and management. Macmillan Pub. Co. Pennsylvania.

Harter, J. K., F. L.Schmidt., danT. L. Hayes. 2002. Business-unit-level relationship between employee satisfaction, employee engagement, and business outcomes: A meta-analysis. Journal of Applied Psychology87(2) : 268-279.

Heneman, R.L., dan D.B. Greenberger. 2002. Human management in virtual organizations. Ohio State University. Columbus

Jakarta Post. 2012. Survey shows Indonesians worry about work-life balance.

http://www.thejakartapost.com/ne ws/2012/11/01/survey-showsindonesians-worry-about-worklife-balance.html

Kular, S., M. Gatenby, C. Rees, E. Soane, dan K. Truss. (2008). Employee Engagement : A Literature Review. Kingston University

May, D.R.,R.L Gilson., dan L. M. Harter. 2004. The psychological conditions ofmeaningfulness, safety and availability and the engagement of the human spirit at 
work.Journal of Occupational and Organisational Psychology 77 (1) : 11-37.

Meadows, V. 2007. Versatile bureaucracy: A telework case study. The Public Manager36(4) : 33-37.

Megani, A. 2012. Hubungan antara employee engagament dan kesiapan karyawan untuk berubah (Studi pada PT. X). Skripsi. Fakultas Psikologi Universitas Indonesia.

Nirmala G. C. (2010). Perbedaan Employee Engagement Ditinjau Dari Jenis Bank Berdasarkan Segi Kepemilikan. Skripsi. Fakultas Psikologi. UNAIR. Indonesia

Olorunfemi, A. O. 2013. Telecommuting to Improve Quality of Worklife of Women Workers in Lagos State Tertiary Institutions. Journal of Studies in Education 3 (2)

Rich, B. L., J.A. Lepine., dan E. R. Crawford. 2010. Job Engagement : Antecedents and Effects on Job Performance. Academy of Management Journal53 (3) : 617-635.

Robbins, S. P., dan T. Judge. 2007. Organizational behavior.
Pearson/Prentice Hall. Upper Saddle River, N.J.

Saks, A.M. 2006. Antecedents and consequences of employee engagement.Journal ofManagerial Psychology 21(6) : 600-619.

Schaufeli, W. B., M. Salanova, danA. B. Bakker. 2006. The Measurement of Work Engagement With a Short Questionnaire : A Cross National Study. Educational and Psychological Measurement 66 (4) : $701-716$

Sukoco, B. M. 2007. Manajemen Administrasi Perkantoran Modern.Erlangga. Indonesia

The Center for Work \& Family. 2002. Bringing Work Home : Advantages and Challenges of Telecommuting. Boston : Elizabeth Hamilton, Boston College

Towers Watson. 2012. Organisations Face a Huge Retention Risk with Nearly Two-thirds of the Indonesian Workforce Not Highly Engaged. Towers Watson. Indonesia

http://www.portalhr.com/berita/jakartabanjir-karyawan-microsoftindonesia-terbantu-sistemtelecommuting/ - diakses 20 November 